\title{
Biological Control of Anthracnose Disease of Tomato Using Ethanolic Extracts of Azadirachta Indica and Nicotiana Tabacum
}

\author{
Bankole Samuel Opeyemi ${ }^{1 *}$, Bankole Ruth Temidayo ${ }^{2}$, Babalola Yetunde Oyinkansade ${ }^{1}$, \\ Emmanuel Ilerioluwa Busayo ${ }^{1}$, Ojubolamo Motunrayo Temitope ${ }^{3}$, Awotedu Bolakale Folake ${ }^{4}$ \\ ${ }^{1}$ Biomedicinal Research Centre, Forestry Research Institute of Nigeria, Ibadan. \\ ${ }^{2}$ Department of Wood and Paper Technology, Federal College of Forestry, Ibadan. \\ ${ }^{3}$ Department of Wildlife and Ecotourism, Forestry Research Institute of Nigeria, Ibadan. \\ ${ }^{4}$ Department of Sustainable Forest Management, Forestry Research Institute of Nigeria, Ibadan. \\ * Corresponding author email: opebanky01@gmail.com
}

Received: 21 December 2017 / Revised: 23 January 2018 / Accepted: 4 February 2018 / Published: 5 February 2018

\begin{abstract}
Tomato is a commercially important vegetable throughout the whole world and its availability all the year is grossly affected by anthracnose disease, hence, the need for an effective bio-control that is affordable and user friendly. This study therefore investigated the inhibitory effect of ethanol extracts of Aradiracbta indica and Tabacum nicotianaon the mycelium growth of fungi associated with anthracnose disease of tomato. Tomatoes that showed black circular lesions with concentric ring and black spores were bought from Aleshinloye market in Ibadan; samples $(3 \times 3 \mathrm{~mm})$ from the sterilized margin of the lesion were inoculated on potato dextrose agar and observed for mycelium growth for five days. The obtained cultures were then sub cultured to obtain pure cultures which were introduced into healthy tomato fruits to confirm koch's postulate. The in-vitro antifungal effects of ethanol extracts of Azadirachta indica and Nicotiana tabacum on isolated fungus causing anthracnose disease of tomato was investigated using agar dilution method. Based on cultural and microscopic characteristics of conidia, Colletotrichum coccodewas identified as organism causing anthracnose disease of tomato. The antifungal effect of the two ethanol plant extracts revealed that Azadirachta indica had the highest inhibitory effect of $(45.00 \mathrm{~cm})$ at $100 \mathrm{mg} / \mathrm{ml}$ and the least effect of $(38.00 \mathrm{~cm})$ at $50 \mathrm{mg} / \mathrm{ml}$. Nicotiana tobacum equally had its highest inhibitory effect of $(58.00 \mathrm{~cm})$ at $100 \mathrm{mg} / \mathrm{ml}$ and lowest effect of $(40.57 \mathrm{~cm})$ at $50 \mathrm{mg} / \mathrm{ml}$. This result also showed that Nicotiana tobacum had the highest inhibitory effect on Colletotrichum coccode than Azadirachta indica. Conclusively, the use of Tobacco and Neem plant extracts has antifungal activity against Colletotrichum which is responsible for Anthracnose disease of tomato. The plant could be a veritable and cheaper substitute for conventional drugs since the plant is easily obtainable and the extract can easily be made via a simple process of maceration or infusion.
\end{abstract}

Keywords: Antifungal, Azadirachta indica, Nicotiana tabacum, Anthracnose, Lycopersicum esculentum, Inhibitory.

\section{Introduction}

Colletotrichum has been identified as one of the most important plant pathogens worldwide causing the economically important disease anthracnose in a wide range of hosts including cereals, legumes, vegetables, perennial crops and tree fruits [1]-[3]. Among the hosts, Tomato, widely consumed in diverse ways all over the world either raw, as ingredient in dishes, sauces, salads and drinks [4], is affected by anthracnose disease caused by Colletotrichum spp the major disease that normally affects quality of tomato 
fruit, and in turn makes it less available in the market by causing post-harvest rot [5], [6]. The fungal (Colletotrichum species) are capable of surviving in infected plant debris and in the soil. During rainy weather, spores of the fungus are splashed onto the fruit. Most infection takes place on ripe or over-ripe fruit. Green fruit also may be infected, although symptoms do not develop until the tomatoes begin to mature, and disease development is favoured by high temperatures [6]. Anthracnose disease is characterized by circular sunken lesions and fruiting bodies at the centre of the lesions on ripening tomatoes, with infected fruit having a short shelf life which may cause massive fruit loss if left uncontrolled [5], [6].

Since post-harvest diseases of tomato are mainly associated with fungal infection, it is necessary to adopt safe and acceptable control measures of fungus associated with anthracnose of tomato. Some researchers have investigated the effect of common fungicides commonly used in tomato production with mixed results [1], also, various control strategies for post-harvest management of tomato fruits ranging from biological, to chemical and physical treatment are also known to have negative trade-offs [4]. Thus, the control and management of Anthracnose disease of tomato is still being researched extensively.

The perceived negative effects of fungicides as a whole on agricultural land and water and their possible toxicity to man and animals has resulted in the consideration of more environmental friendly control measures. As a result, attention is shifting to the use of plant based extracts to find one that will control the anthracnose disease of tomatoes as agricultural chemicals have been identified to be responsible for environmental pollution and inducing pest resistance in targeted pathogens [4], [7]. Plant extracts of Azadirachtaindica, Chromolaena odorata, Vernonia amigdalina and Tridax procumbens at various concentrations have been reported to have antifungal activity against tomato rot [8]. This paper investigated the effect of ethanol leaf extracts of Azadirachtaindica and Nicotiana tabacum on the fungi associated with Anthracnose disease of tomato.

\section{Materials and Methods}

\subsection{Materials Used}

Healthy tomato fruits, Diseased tomato (Figure 1), Neem leaves, Tobacco leaves, Petri dishes, Methylated Spirit Lamp, Mortar and Pestle, Cork borer, Inoculating loop, Cotton wool, Ethanol, Potato dextrose agar, Specimen bottles, Paper tape, syringe, Autoclave, Conical flask, Water bath.

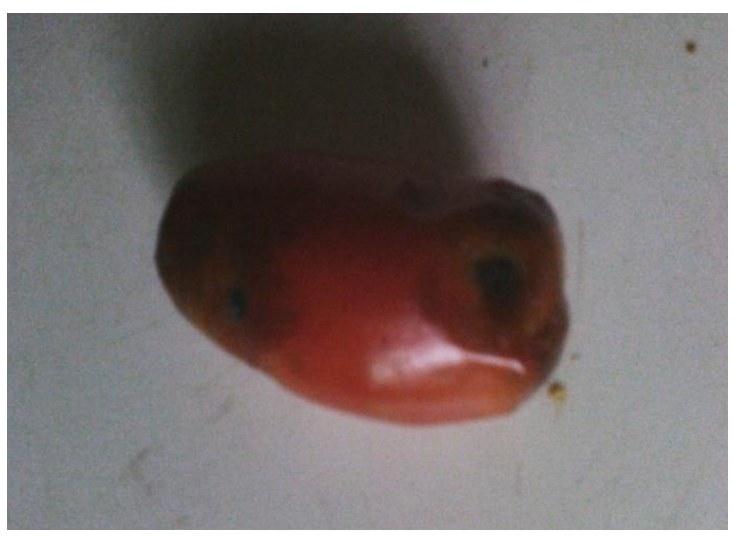

Figure 1: Diseased Tomato (Sample of tomato fruit being affected by Anthracnose disease used for this experiment.)

\subsection{Isolation of Fungi}

Infected tomato fruits were collected from the market. The tomato showed black circular lesions with concentric ring, and the surface consisting many small, black spores. The diameter of the lesions was up to $3 \mathrm{~mm}$. A small sample from the margin of a lesion of the tomato was transferred to a PDA plate using a sterile scalpel. After a week, the PDA plate was covered with mycelium colony. To obtain a pure culture, a small mycelium colony sample that was actively growing at the margin was isolated and transferred to a newly prepared PDA plates.

\subsection{Broth Preparation}

$5 \mathrm{~g}$ of potato dextrose agar was weighed inside conical flask and it was mixed with $250 \mathrm{ml}$ distilled water and sterilized, after sterilization the solution inside the flask was allowed to settle, the supernatant was decanted into another flask, this was allowed to settle for some minutes. The supernatant was inoculated with pure culture of the fungus. 
Bankole et al., Int. Ann. Sci.; Vol. 4 Issue 1, pp: 20-26, 2018

\subsection{Pathogenicity Test}

Cylindrical cores of $1 \mathrm{~cm}$ deep were taken away from different spots of a fresh and healthy tomato fruits with the aid of sterile $6 \mathrm{~mm}$ cork borer and then disk of $4 \mathrm{~mm}$ discs taken from the periphery / core of a colony of five days old test fungus was placed downward into each hole in the tomato fruit. It was examined for lesion development 7 days after inoculation. Control fruit was inoculated with $20 \mu$ l of sterile distilled water. After 14 days, spores from diseased fruits were aseptically transferred and sub-cultured onto PDA plates, which were incubated at $25^{\circ} \mathrm{C}$ in darkness. The resultant cultures were checked for colony and spore morphology to confirm Koch's postulate.

Tomato fruit inoculated with pure culture of Colletotrichumcoccode, showing circular sunken lesion after 7 days of incubation as shown in Figure 2.

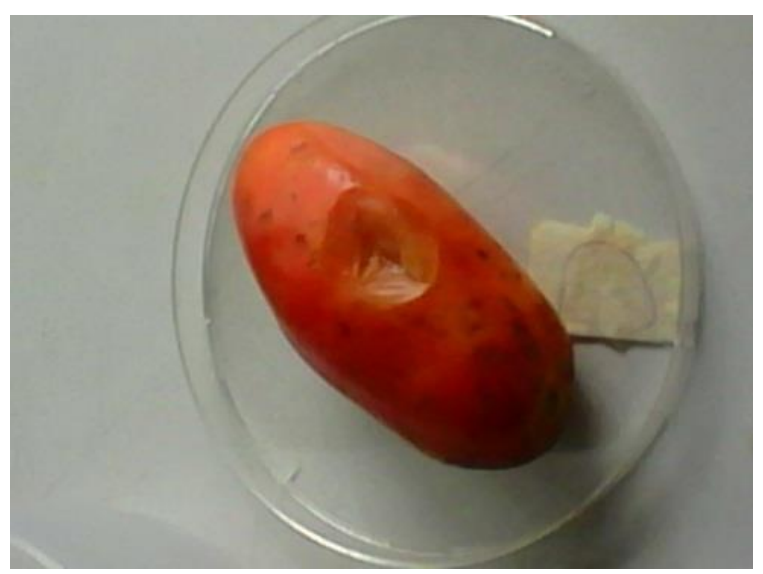

Figure 2: Tomato Innoculated with Fungi Associated with Anthracnose of Tomato

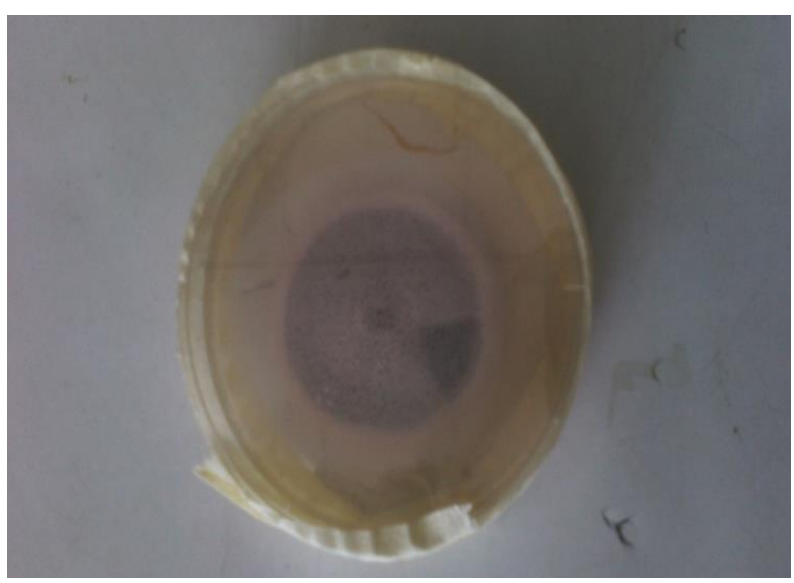

Mycelial growth of the fungi initially appears white and later turned black as the culture age (Figure 3). Figure 4 shows the microscopic examination of colletotrichum coccodes, its reveals conidia that is cylindrical, hyaline and aseptate.

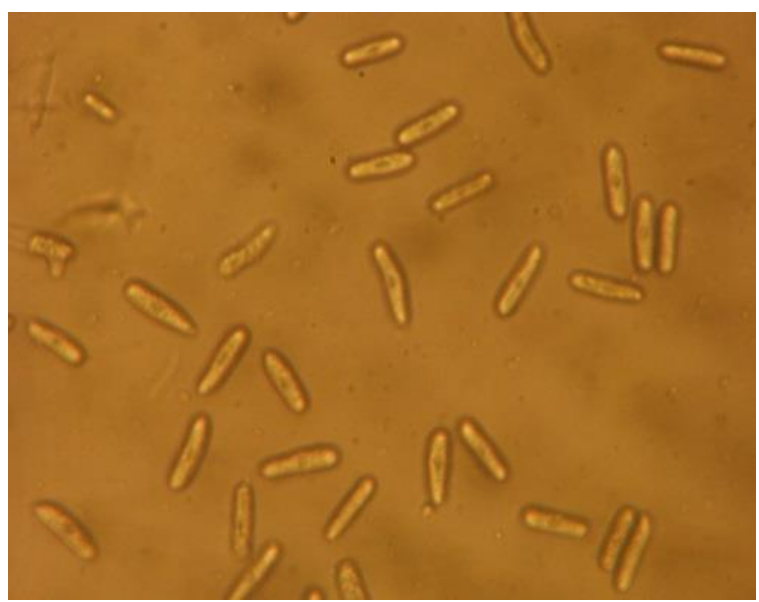

Figure 4: Conidia of Colletotrichum coccodes

\subsection{Preparation of Plant Extracts}

Leaves of Tobacco (Nicotianatabacum) and Neem (Azadiracthaindica) plants were taken to the herbarium unit of the Forestry research institute of Nigeria (FRIN) for Identification. The leaves were washed with water to remove the sand and it was air dried, the powder of each was macerated in ethanol and left for $24 \mathrm{hrs}$. The filtrate was separated from the residue by using four - fold filter paper. The filtrate was concentrated using water bath.

\subsection{Preparation of Different Concentrations of the Extracts}

Different concentration used in this work was prepared from $4 \mathrm{~g}(100 \mathrm{mg} / \mathrm{ml}, 75 \mathrm{mg} / \mathrm{ml}, 50$ $\mathrm{mg} / \mathrm{ml}$, and $25 \mathrm{mg} / \mathrm{ml}) .1 \mathrm{~g}$ of the plant extracts were weighed from each plant extract with adding of $10 \mathrm{ml}$ of distilled water to give concentration of $100 \mathrm{mg} / \mathrm{ml}$. $0.75 \mathrm{~g}$ of the plant extracts with adding of $10 \mathrm{ml}$ distilled water to give concentration of $75 \mathrm{mg} / \mathrm{ml}$. $0.5 \mathrm{~g}$ of the plant extracts with addition of $10 \mathrm{ml}$ distilled water to give concentration of $50 \mathrm{mg} / \mathrm{ml} .0 .25 \mathrm{~g}$ of the plant extracts with addition of $10 \mathrm{ml}$ distilled water to give concentration of $25 \mathrm{mg} / \mathrm{ml}$.

Figure 3: Pure Culture of Collectotrichumcoccodes 


\subsection{Preparation of Potato Dextrose Agar}

Thirty-nine grams (39g) of Potato Dextrose agar was dissolved in one liter of distilled water and the medium was autoclaved at $121^{\circ} \mathrm{C}$ pressure for 15 minutes. Six milliliters $(0.1 \%)$ of streptomycin was added to the 1 litre of the sterilized media just before pouring into Petri-dishes, to prevent the growth of bacteria and allowed to cool and solidify. A sterile syringe was used to evenly distribute fungi broth over potato dextrose agar (PDA). The plate was allowed to dry for 30 minutes. The medium was bored with $6 \mathrm{~mm}$ diameter sterile cork borer to create wells and these were filled with $1 \mathrm{~m}$ plant extracts each all were tested in triplicate, it was allowed to diffuse at room temperature. Fungus growth was determined by measuring the diameter of zone of inhibition (Figure $5-6$ ), data generated was subjected to statistical analysis where analysis of variance was employed followed by Duncan test to separate significant means at $\mathrm{P}<0.05$.
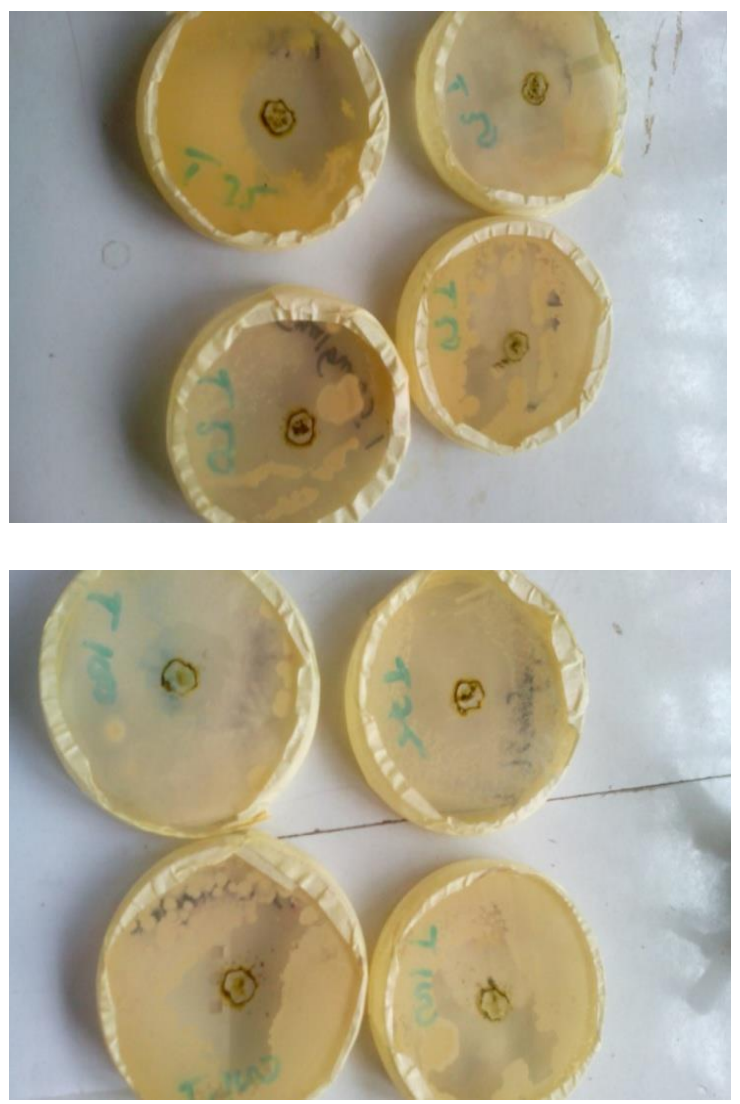

Figure5: Zones of Inhibition Exhibited by Ethanol Extract of Nicotianatabacumat Different

Concentrations $(100 \mathrm{mg} / \mathrm{ml}, 75 \mathrm{mg} / \mathrm{ml}, 50 \mathrm{mg} / \mathrm{ml}$, $25 \mathrm{mg} / \mathrm{ml})$
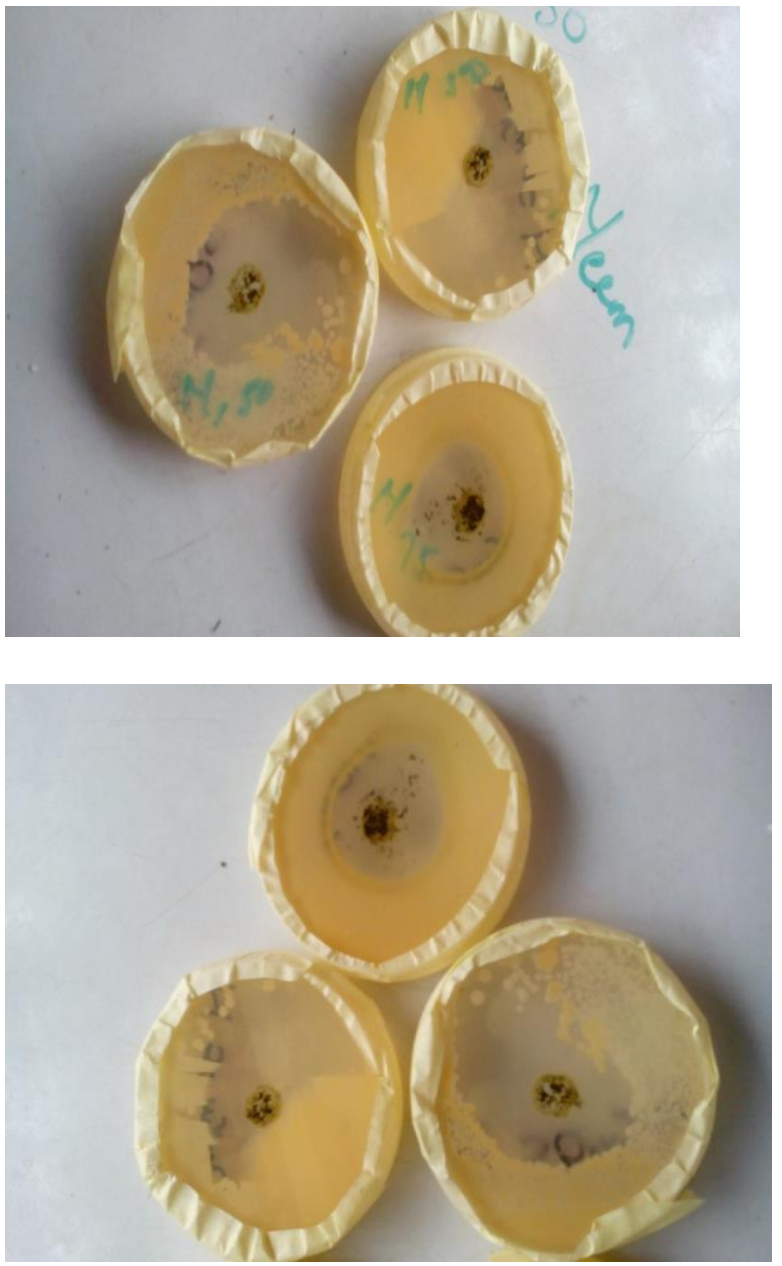

Figure 6: Zones of Inhibition by Ethanol Extract of Azadirachta indica at Different Concentrations (100 mg/ml, $75 \mathrm{mg} / \mathrm{ml}, 50 \mathrm{mg} / \mathrm{ml}, 25 \mathrm{mg} / \mathrm{ml}$ )

\section{Results and Discussion}

\subsection{Morphological Description}

Colonies of tomato were initially white and later turned dark as the culture aged on PDA (Figure 3). The culture developed black acervuli around the centre of the colony.

\subsection{Result of Microscopic Description}

Microscopic examination of fruiting structures reveals conidia that are cylindrical, hyaline and aseptate $(16-25 \mu \mathrm{m} \times 3-4 \mu \mathrm{m})$ formed on cylindrical conidiophores (Figure 4).

\subsection{Result of Pathogenicity Test}

The tested isolate which was inoculated into healthy tomato caused anthracnose lesions on the tomato fruit after 7 days of incubation (Figure 2). No lesions developed on tomato fruit inoculated 
Bankole et al., Int. Ann. Sci.; Vol. 4 Issue 1, pp: 20-26, 2018

with water. Koch postulate were fulfilled by reisolation from inoculated tomato fruits.

\subsection{Effect of Ethanol Extract of Tobacco and Neemon Colletotrichum cocodes}

Figure 7 to 9shows the Zone of Inhibition of plant extracts of Neem and Tobacco used at different concentration on the mycelia growth of fungi associated with anthracnose of tomatoes after 48, 72 and 96 hours of exposure respectively.

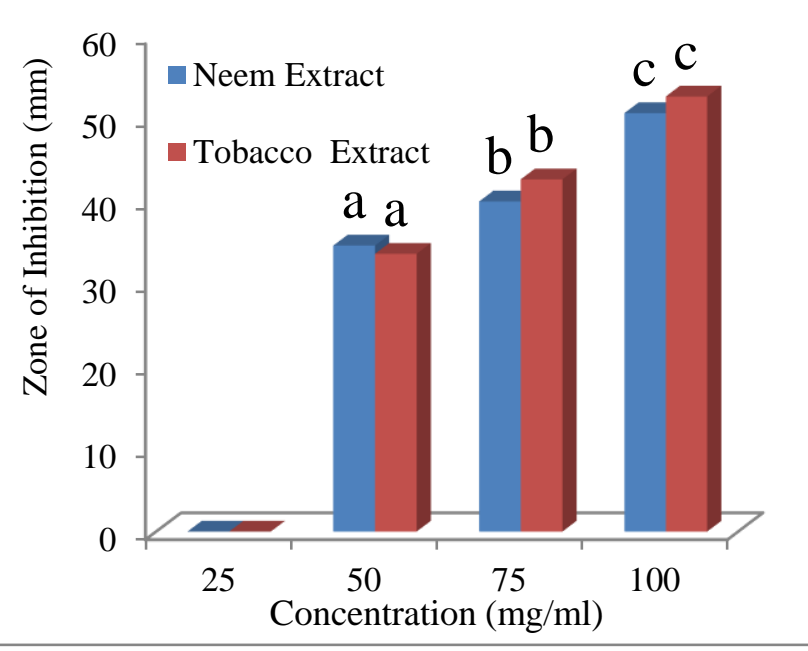

Figure 7: Comparative Zone of Inhibition of Azadirachtaindica and Nicotianatabacum extract after 48hrs. Means with the same alphabet are not significantly different $p<0.05$.

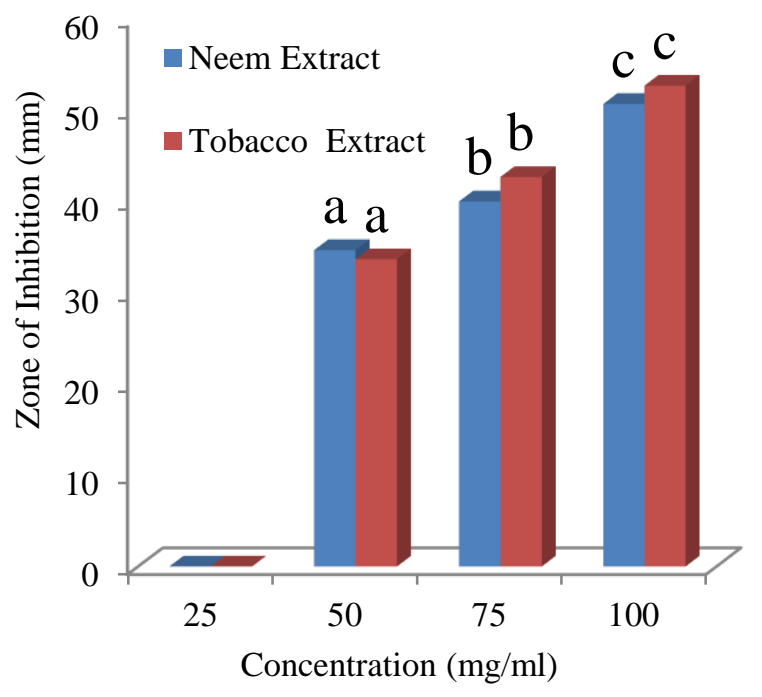

Figure 8: Comparative Zone of Inhibition of Azadirachtaindica and Nicotianatabacum extract after $72 \mathrm{hrs}$. Means with the same alphabet are not significantly different $p<0.05$.
The biological effect of the two ethanol plant extracts revealed a dose dependent action with Azadirachtaindica having its highest inhibitory effect of $(45.00 \mathrm{~mm})$ at $100 \mathrm{mg} / \mathrm{ml}$ and the least effect of $(38.00 \mathrm{~cm})$ at $50 \mathrm{mg} / \mathrm{ml}$, whileNicotianatabacum equally had its highest inhibitory effect at $100 \mathrm{mg} / \mathrm{ml}(58.00 \mathrm{~mm})$ and lowest effect of $(40.57 \mathrm{~mm})$ at $50 \mathrm{mg} / \mathrm{ml}$ after $96 \mathrm{hrs}$ of exposure. This result also showed that Nicotianatabacum had a significantly higher $\mathrm{p}<0.05$ inhibitory effect on Colletotrichumcoccodethan Azadirachtaindica. Both the plant extracts have ability to inhibit the growth of fungus associated with Anthracnose of tomato, the higher the concentration of the plant extracts, the higher the zone of inhibition.

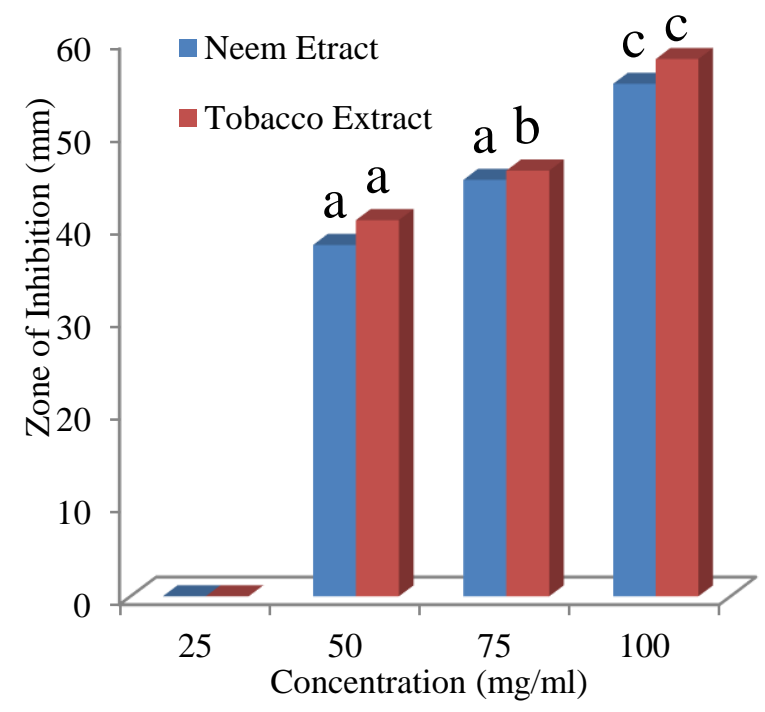

Figure 9: Comparative Zone of Inhibition of Azadirachtaindica and Nicotianatabacum extract after 96hrs. Means with the same alphabet are not significantly different $p<0.05$.

In this study, biological activities of Neem and Tobacco were evaluated on fungus associated with Anthracnose of tomato. Colletotrichumcoccodes has a large host range. Solanaceous species are susceptible to Colletotrichumcoccodes. Tomato is infected by this pathogen and the disease is anthracnose fruit rot. Cucumber, legumes, mint, peppers and weeds are common hosts of the pathogen. Nightshade, a weed species commonly found in agriculture production systems, has been 
observed to harbour the fungus and aid in overwintering. Study also shows that tobacco as medicinal plant, possess potential antifungal properties which inhibit fungal mycelia growth. Colletotrichumwas identified as the causative organism responsible for Anthracnose disease of tomato. Greater inhibitions of fungal growth were observed in ethanol extract of Tobacco while ethanol extract of Neem shows lesser zone of inhibition; this is in agreement with other researcher [9] who worked on Antifungal properties of leaf extracts of Neem and Tobacco on three fungal pathogens of tomato. Tobacco (Nicotianatobacum)extract which is also economically friendly and medicinal can be used for the control ofplant diseases. The results showed that the mycelial growth of Colletotrichum decreasedwith increase in concentrations. The inhibitory effect of the plant extract might be attributed to the presence of secondary metabolites in the medicinal plants. Ethanol extracts of Azadirachtaindicainhibit the fungal growth of Colletotrichumcoccodes at different concentrations. Similar result was also found in a research article [10] with leaf extracts of Azadirachtaindicaand Ocimum sanctum against Fusarimoxysporium, the causal agent of banana fruit rot. Researcher [13] showed that neem leaf extract was effective in reducing early blight incidence with increased yield of tomato infected by Alternariasolani. Plants are rich in a wide variety of secondary metabolites with antimicrobial properties, such as tannins, terpenoids, alkaloids and flavonoids [11]-[17].The abundance of medicinal plants in nature and the traditional knowledge increase the understanding of the medicinal plants properties, safety and efficacy. Findings from this study confirmed that plant extracts can be used as natural fungicides to control pathogenic fungi, thus reducing the dependence on the synthetic fungicides.

\section{Conclusion}

The study shows that Tobacco and Neem plant extracts has antifungal activity against Colletotrichum which is responsible for Anthracnose disease of tomato. These plants could be a veritable and cheaper substitute for conventional drugs since the plants are easily obtainable and the extracts can easily be made via a simple process of maceration or infusion. Based on the findings of this study and conclusion drawn, it is therefore recommended that plant extracts of Nicotinatobacumshould be adopted as an alternative fungicide instead of synthetic fungicides which may have adverse effect on the health of people who consume the tomato fruit.Hence the use of plant extracts could be adopted to meet this demand with minimal or no side effects and its environmental friendly. Nicotinatobacum and Azadirachtaindica possess good anti-fungal activity rationalizing the use of this plant in plants and human health care. These antibiotic principles are actually defensive mechanism of the plant against different pathogens. Further studies should be done on the botanicals so as to know the specific active ingredient that control fungi associated with Anthracnose disease of Tomatoes. It is essential that research should continue to isolate and purify the active components of this natural herb. Further work is required to increase the efficacy of these plant extracts in the field and also to determine the biologically active ingredient present in extracts as well as its mode of action.

\section{How to Cite this Article}

Bankole et al "Biological Control of Anthracnose Disease of Tomato Using Ethanolic Extracts of Azadirachta Indica and Nicotiana Tabacum", International Annals of Science, vol. 4, no. 1, pp. 20-26, Feb. 2018. doi: $\underline{10.21467 / \text { ias.4.1.20-26 }}$

\section{References}

[1] L. J. G. Chapin, Y. Wang, E. Lutton, and B. B. M. Gardener, "Distribution and Fungicide Sensitivity of Fungal Pathogens Causing Anthracnose-like Lesions on Tomatoes Grown in Ohio," Plant Dis., vol. 90, no. 4, pp. 397-403, Apr. 2006.

[2] P. P. Than, H. Prihastuti, S. Phoulivong, P. W. J. Taylor, and K. D. Hyde, "Chilli anthracnose disease caused by Colletotrichum species," J. Zhejiang Univ. Sci. B, vol. 9, no. 10, pp. 764-778, Oct. 2008.

[3] Y.-Z. Diao et al., "Colletotrichum species causing anthracnose disease of chili in China," Persoonia - Mol. Phylogeny Evol. Fungi, vol. 38, no. 1, pp. 20-37, Jun. 2017.

[4] E. Etebu, A. B. Nwauzoma, and D. D. S. Bawo, Journal of Biology, Agriculture and Healthcare, vol. 3, no. 10. International Institute for Science, Technology and Education (IISTE), 2011.

[5] A. H. Wani, "An overview of the fungal rot of tomato," Mycopath, vol. 9, no. 1, pp. 33-38, 2011.

[6] R. Sanoubar and L. Barbanti, "Fungal diseases on 
Bankole et al., Int. Ann. Sci.; Vol. 4 Issue 1, pp: 20-26, 2018

tomato plant under greenhouse condition," Eur. J. Biol. Res., 2017.

[7] R. N. Okigbo and F. E. O. Ikediugwu, "Studies on Biological Control of Postharvest Rot in Yams (Dioscorea spp.) using Trichoderma viride," $J$. Phytopathol., vol. 148, no. 6, pp. 351-355, Jun. 2000.

[8] I. J. A, "Antifungal effects of four tropical plant aqueous and ethanol extracts on post harvest rot of tomato (Lycopersicum esculentum) in Ado-Ekiti, Nigeria," New York Sci. J., vol. 44, no. 11, pp. 64-68, 2011.

[9] M. N. Suleiman, "Antifungal properties of leaf extract of neem and tobacco on three fungal pathogens of tomato (Lycopersicon Esculentum Mill)," Adv. Appl. Sci. Res., vol. 2, no. 4, pp. 217-220, 2011.

[10] H. N. P. Singh, M. M. Prasad, and K. K. Sinha, "Efficacy of leaf extracts of some medicinal plants against disease development in banana," Lett. Appl. Microbiol., vol. 17, no. 6, pp. 269-271, Dec. 1993.

[11] W. Al-Momani, E. Abu-Basha, S. Janakat, R. A. J. Nicholas, and R. D. Ayling, "In vitro antimycoplasmal activity of six Jordanian medicinal plants against three Mycoplasma species," Trop. Anim. Health Prod., vol. 39, no. 7, pp. 515-519, Sep. 2007.

[12] G. Bisignano et al., "Antimicrobial activity of Mitracarpus scaber extract and isolated constituents," Lett. Appl. Microbiol., vol. 30, no. 2, pp. 105-108, Feb. 2000.

[13] M. L. M. Bouzada, R. L. Fabri, M. Nogueira, T. U. P. Konno, G. G. Duarte, and E. Scio, "Antibacterial, cytotoxic and phytochemical screening of some traditional medicinal plants in Brazil," Pharm. Biol., vol. 47, no. 1, pp. 44-52, Jan. 2009.

[14] A. Chakraborty and A. H. Brantner, "Antibacterial steroid alkaloids from the stem bark of Holarrhena pubescens," J. Ethnopharmacol., vol. 68, no. 1-3, pp. 339-344, Dec. 1999.

[15] M. M. Cowan, "Plant products as antimicrobial agents.," Clin. Microbiol. Rev., vol. 12, no. 4, pp. 56482, Oct. 1999.

[16] W. N. Setzer, M. C. Setzer, R. B. Bates, and B. R. Jackes, "Biologically Active Triterpenoids of Syncarpia glomulifera Bark Extract from Paluma, North Queensland, Australia," Planta Med., vol. 66, no. 2, pp. 176-177, Mar. 2000.

[17] M. Nouman Soh, A. Karim, M. Sarwar, and A. M. Alhasin, "Onion (Allium cepa L.): An Alternate Medicine For Pakistani Population," Int. J. Pharmacol., vol. 7, no. 6, pp. 736-744, Jun. 2011.
Publish your research article in AIJR journals-

$\checkmark$ Online Submission and Tracking

$\checkmark$ Peer-Reviewed

$\checkmark$ Rapid decision

$\checkmark \quad$ Immediate Publication after acceptance

$\checkmark \quad$ Articles freely available online

$\checkmark \quad$ Retain full copyright of your article.

Submit vour article at journals.aijr.in

\section{Publish your books with AIJR publisher-}

$\checkmark$ Publish with ISBN and DOI.

$\checkmark$ Publish Thesis/Dissertation as Monograph.

$\checkmark$ Publish Book Monograph.

$\checkmark$ Publish Edited Volume/ Book.

$\checkmark$ Publish Conference Proceedings

$\checkmark \quad$ Retain full copyright of your books.

Submit your manuscript at books.aijr.org 